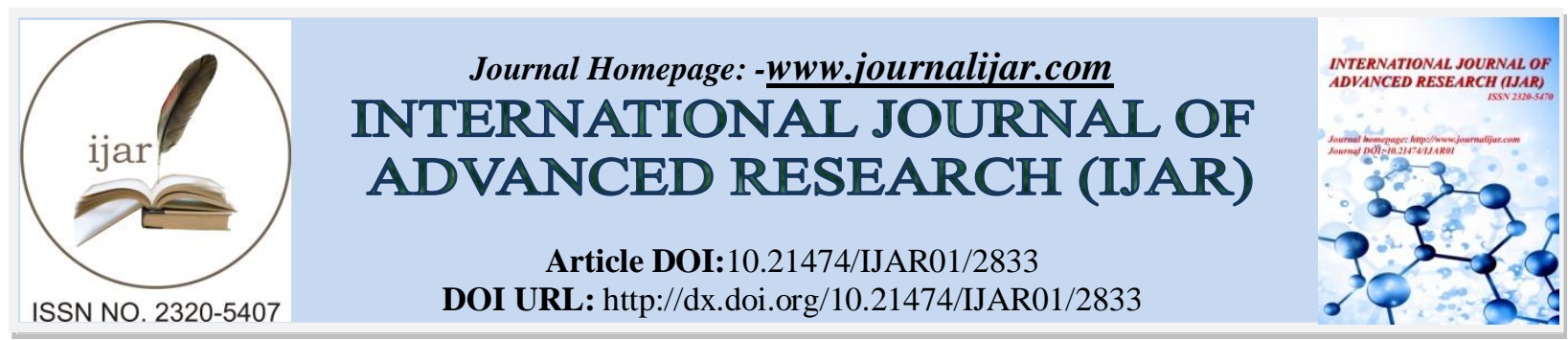

RESEARCH ARTICLE

Comparative Study of E-marketing In India \& China.

Soumya Pandey

\section{Manuscript Info}

Manuscript History

Received: 18 November 2016

Final Accepted: 19 December 2016

Published: January 2017

\section{Abstract}

\title{
Research objectives:-
}

- To analyze about the importance of e-marketing in present scenario.

- To determine the difference of e-marketing between two countries: India \& China.

- Current scenario of E-marketing in India and China and its impact on current markets.

- To know the online marketing methods of India and study Chinese consumer behavior.

- $\quad$ To forecast the future prospects of e-marketing in India \& China.

\section{Introduction:-}

Any business process performed electronically is called e-business and today most of the business processes like recruitment, e-commerce, e-information, e-auction, e-marketing and so on, are being performed through e-business.

E-marketing stands for 'electronic showcasing'. E-marketing is the idea that associate the reasonable and graphical parts of online instruments together, taking into account the reason, outline, exposure, brand improvement, advancement and deals.

\section{Benefits of E-marketing:-}

1. Global reach: A website can reach anywhere in the whole world who has the internet connection. We are just a search or a click of a button away from any internet source.

2. Cost Effective: It is very cheap and cost effective in terms of spending money on advertising on social media sites and other website as compared to broadcasting messages on radio and television in a particular timeslot period.

3. 24/7 online shopping: The website enables communication with the customers at any point of time ( 24 hours*7 days a week). They guide the customers about the product line in depth so that they can be fully educated.

4. Website content has to be interactive and entertaining: Unlike printed words or television, there is a possibility of opening up two-way communication with the customer.

This can occur as simply as an instant email response to customers and as complex as a regularly updated blog.

\section{E-marketing tools:}

- Search Engine Optimization

- Paid search

- Display Advertising 
- Sponsorship

- Social Networking

- Blogging

When setting the e-marketing objectives, we need to make sure that they are:

- Specific: to specify what is to be achieved.

- Measurable: to express in measurable terms such as key performance indicators, outcomes, numbers, percentage, etc.

- Action-oriented: to state which actions need to be taken and who will take them.

- Time specific: to establish specified time frames.

- To increase online sales for all the products by $15 \%$ in the upcoming year trends.

- To grow email coverage to $50 \%$ of the current customers base by the end of the next year.

- Realistic: achievable with the resources available.

\section{Research methodology:-}

Research Methodology is the way used to collect information and data for the purpose of making business decisions. The methodology may include publication research, interviews, surveys and other research practices, and could comprise both present and historic information.

There are basically two types of Research:

1. Descriptive

2. Exploratory

Data Collection Method: Data collection methods often used in program evaluations include literature search, file review, natural observations, surveys, expert opinions and case studies.

There are two types of data collection methods:

1. Primary Data: Data collected by an evaluation team specifically for the evaluation study.

2. Secondary Data: Data collected and recorded by another person or organization, usually for different purposes than the current evaluations.

Hereby, the current research is conducted through the information received from secondary sources such as:

1. Websites

2. Journals

3. Books.

\section{Analysis of study:-}

Key drivers in Indian e-commerce are:

- Increasing the broadband internet connection and $3 \mathrm{G}$ penetrations across the country.

- Convenience of less availability of product ranges.

- Busy lifestyles, urban tie ups and the lack of our time for offline searching.

- Increasing usage of online classified sites, with a lot of consumers shopping for and merchandising second hand products.

E-commerce market in India was valued \$2.5 billion in 2010, and it went up to \$6.3 billion in 2011 and to \$14 billion in 2012. And basically $75 \%$ of that total value was related to airline tickets, railway tickets, building bookings and online mobile recharge etc. On March 7, 2014 E-retailer FLIPKART claimed its hit of $\$ 1$ billion sales, a deed it has managed to attain before its own target (2015).

Online retail in China generated $\$ 121$ billion sales last year, up 66\% as compared to 2012.There are various factors for growth in China. Its impressively awesome that the online Chinese markets, ALIBABA and TAOBAO business is estimated that half of all the packets sent to the total account of China.

Examples of Indian internet companies with innovative business models:-

- Naukri.com: It is the leader in Indian online job market. It offers free SMS-based job notifications, call centers with all the value added services. 
- Flipkart: It's a pioneer in e-commerce in India. It has popularized the concept of online retail and has started its own logistics operations with 1500 employees. It even offers cash-on-delivery services in response to Indian consumer's low propensity to use cashless transactions

- Redbus: It was launched in 2006. Redbus.in is an online bus-ticketing portal with the current customer base of nearly 2 millions. It primarily reaches customers through online platform. It has also introduced cash-ondelivery system due to customer's reluctance to use online payment methods.

\section{China's major market leading player companies:-}

The three big Internet market leading companies in China are ALIBABA, BAIDU, TENCENT, which dominate the three different categories of the market mainly: e-commerce, search and messaging, respectively. The vast majority of the online transactions happens in China which is around $85 \%$ as of 2009, that take place between consumers, ALIBABA-owned TAOBAO, is often described as the "eBay of China."

Like eBay, users on Taobao can usually purchase and sell new \& used items at fixed or assigned prices, as well as through auction listings. Unlike eBay, most of the goods or items are new and there is no listing fees, the majority of the Taobao's income revenue comes from the advertising. Next year the company would bring in $\$ 700$ million pretax earnings and would be worth $\$ 14$ billion.

\section{China's Search Engine Marketing Planning and Execution:-}

1. Chinese SEO keyword research.

2. On-site SEO of Chinese web pages

3. Off-site SEO and online management/ online word of mouth marketing.

China's retargeting banner and display stressing/promotion:

1. Defining the Chinese targeted audience.

2. Defining the goals of the digital media.

3. Defining a China media way out.

\section{Methods of online marketing common in India:}

1. Social network

2. Online favorites and bookmarking

3. Blogging

4. E-mail marketing

5. Search engines

6. Pay-per-click advertising

7. Press release

\section{Learning outcomes:-}

Comparative study of e-marketing in India and China:-

$>$ From the study related to the topic "Comparative study of e-marketing in India and China", it can be clearly stated that e-commerce scope is widely increasing at a fast pace.Total sales in Asia-pacific region exceeds sales in North America and Europe combined.

$>$ It's obvious that e-commerce in China and India is expected to grow quickly between in the years 2014 and 2018.

$>$ At present, the Chinese e-commerce market is wholly dominated by Alibaba cluster, Taobao owner and sister Tmall web site. Together these 2 sites which are held by Alibaba cluster signify relatively $1 / 2$ online purchases by Chinese customers.

$>$ India, for the instant, it's estimated that the marketplace for e-commerce developed beneath 5\% grow terribly quickly, at the rate of over 505 per projections by Forrester, the web retail can grow from U.S. $\$ 2$ billion in 2013 to over U.S. \$ 16 billion in 2018.

$>$ If FDI are given the clearance to enter Indian markets, Indian e-commerce e-retailing websites would definitely face a severe drawback as many of the online buyers would definitely migrate to other FDI e-retailing companies. At instance, there would not be any issue regarding this but later in the upcoming online shopping trend it would be a gain to foreign companies.

$>$ It has clearly shown that e-marketing influences upon businesses in a number of important ways. When used efficiently, e-marketing campaigns and strategies have the potential to reach customers in a speedy and low-cost manner and could definitely provide promotion for a wide range of products and services. 
$>$ The development of e-marketing and social media advertising has led to examples of businesses in recent years that appear to little more than categories and filter information relating to products and services on the internet, taking a small cut from any transaction that may occur as a result.

$>$ The following five tips can surely help to alter a non-performing website into an efficient sales and marketing tool:

1. Use control to get repeat visitors to the site, not showiness.

2. Make sure that the potential customers can find the website on any search engines.

3. Develop habitual e-newsletters \& announcements to inform \& keep up to date with current and potential customers (to only those who ask for them).

4. Make sure that the website content is focused on customer's needs and interest, not company.

\section{References:-}

1. Simon, F.L. (1992). Marketing green products in the triad. Columbia Journal of World Business, 27(FallWinter), 269-285.

2. Simula, H., Lehtimark, T. \&Salo, J. (2009). Journal of Systems and Information Technology, 11(4), 331-346. 